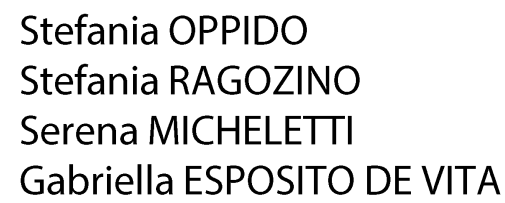

\title{
Sharing responsibilities to regenerate publicness and cultural values of marginalized landscapes: Case of Alta Irpinia, Italy
}

\begin{abstract}
The paper deals with the issue of non-core areas in Italy by investigating the role that publicness and socio-cultural values of landscape can play in triggering development process in these contexts. Local communities have historically been the main producers of the cultural landscape. Nowadays, the importance of involving communities and sharing responsibilities together with policy makers and stakeholders is increasingly recognized. Their involvement is particularly valuable for processes that aim at safeguarding publicness and cultural values of places as well as for achieving social needs, carrying out economic activities, and promoting cultural assets. This research looks at Italian non-core areas in order to investigate the role of the "landscape community" in collaborative regeneration strategies. The aim is to highlight the power of landscape as a catalyst of civic activation and as the place in which to improve social practices for local development, competitiveness and attractiveness by using territorial capital and by strengthening territorial cohesion. For this purpose, Alta Irpinia, in Southern Italy, has been selected for empirical research. Preliminary evidence indicates the presence of bottom-up initiatives for reusing the historical Avellino-Rocchetta Sant'Antonio railway to promote the cultural landscape of the area and contrasting its marginalization. The main output of the ongoing research activity is the definition of the "action arena" to rearrange fragmented and conflicting perspectives and to start a collaborative process for local development in which the landscape could be recognized as driver.
\end{abstract}

Keywords: non-core areas, landscape, community, bottom-up approach, action research

\section{Introduction}

Regeneration strategies of non-core areas constitute a relevant challenge to mitigate territorial inequalities that exist in many national contexts. Progressively deprived of basic services, these areas are often prone to abandonment, decay, emptiness and depopulation: a marginalization process that increases the gap between core and non-core areas (Barca, 2009). In Italy, these areas amount to about $60 \%$ of the national territory, and to about $25 \%$ of its population. They are often characterized by the presence of un(der)used built environment, infrastructural heritage, environmental, historical, cultural and socio-economic resources, "[...] much untapped natural and human capital, seen as strategic for the recovery and growth of Italy's economic system" (UVAL, 2014: 3), as highlighted in the National Strategy for Inner Areas. These characteristics pose a question of high social relevance, namely which places and resources must be mobilized to enhance territorial capital and social relationships and especially to strengthen social cohesion, which are the main goals of the National Strategy (Barca, 2016). In these contexts, social relationships, conviviality and leisure take place not only in the small villages but also in the open spaces of surrounding landscapes. For this reason, it is necessary to widen the field of investigation, including parks, natural reserves, rural pathways networks, and eco-museum systems to recognize their publicness and socio-cultural values. These open 
spaces need to be built taking into account public's needs to reconnect with the natural environment, to provide places for recreation, to give an equal public access and to provide places where diverse population can meet and interact (Németh \& Schmidt, 2011).

Against this background, authors explore whether the landscape in marginalized areas can be intended as place of publicness, as place of communities, as place of memory and collective identity but also as place for well-being, leisure, social interaction, and conviviality. In this perspective, the starting point is to share knowledge of the "territorial capital" (Camagni et al., 2009), involving all the local key actors in recognizing landscape resources, values and opportunities in terms of local development in order to strengthen or build "landscape community" (Ita. Comunità di paesaggio) (Carta di Siena, 2014). For this purpose, the research questions are: What role can the local community play in sharing responsibility for reversing marginalization processes in non-core areas? Can the landscape be the catalyst of social practices to activate new cultural, social, economic dynamics for a regeneration process of these areas?

Starting from these questions, the research deals with regeneration strategies in Italian non-core areas based on a collaborative approach that considers landscape as a common good: a socioeconomic, cultural and healthy environment (Makhzoumi et al., 2011; Settis, 2013) that catalyses civic activation (Magnaghi, 2006; Poli, 2015). Specifically, the paper reports on the first steps of the ongoing research for building an action arena as support for a collaborative, co-design process through Action Research (AR). The aim is to improve the interpretation and representation of cultural landscape by taking into account "the value attached by each heritage community to the cultural heritage with which it identifies" (Council of Europe, 2005, article 12).

The selected case study is Alta Irpinia in Campania Region (Southern Italy). In the last years, the area was characterized by bottom-up initiatives and civic activism, which focused on the landscape as key factor for contrasting the marginalization process (Oppido et al, 2017). The historical Avellino-Rocchetta Sant'Antonio railway, disused since 2010, crosses the exceptional landscape of this area. Evidence from the case highlighted a wide network of civic activism, enthusiastic for enhancing the historical railway as a driver to revive the cultural heritage of the area. This activism preceded and urged the subsequent institutional initiatives for the reuse of the railway (Oppido et al., 2017). Considering both the characteristics of the case study and the aims of the research, AR has been selected to engage with local actors and communities; share knowledge, problems and aims with them; and involve them in an interactive, collaborative and learning-based process to reverse the marginalization of the area.

\section{Collaborative processes for landscape}

In the European context, a cultural change has been registered in the ways the landscape issues are being dealt with. This change is based on the recognition that landscape "has an important public interest role in the cultural, ecological, environmental and social fields", that it represents "a key element of individual and social well-being and that its protection, management and planning entail rights and responsibilities for everyone" (States of the Council of Europe, 2000: 1). This contemporary approach regards the landscape as a cultural and socio-economic construction that is strongly related to society, thus overcoming an aesthetic approach and linking territorial heritage, community and local identity. 
The scientific and cultural debate on landscape issues draws on approaches and experts from different disciplines - such as architects and planners, geographers, sociologists, economists, anthropologists, landscape ecologists - and highlights many studies focused on functions and values of landscape, investigating the contribution of landscape to cultural identity and diversity, and to ecological system (Stephenson, 2007, 2008). In the European Landscape Convention, landscape is understood as the result of the relationships that the inhabitants established with the territory along centuries, pointing out that "culture and identity are therefore not just about social relationships, but are also profoundly spatial. Inappropriate landscape development can change or obliterate locally distinctive characteristics and cultural meanings, creating a break between communities and their past" (Antrop, 2005: 22). This current debate also points to the social demand for landscape, both by insiders and outsiders: different groups can recognize different tangible and intangible values and ask for different uses (Selman, 2006).

The emphasis on the landscape as a primary source of territorial identification and quality of life, resulting from the relationships that people established with their territory, highlights the role of local communities that historically produced it and which today may constitute the key actors for its maintenance, conservation, and enhancement (Bonesio, 2007; Magnaghi, 2010a; Becattini, 2015). The role of community is also emphasized by the Explanatory Report of the European Landscape Convention (Internet 9), which regards the landscape as a matter that affects all citizens and which must be dealt with in a democratic way. This means that citizens, together with policy makers and stakeholders, must share responsibilities about decisions on conservation/transformation issues, not only in order to safeguard the quality and the identity of places but also to achieve social needs, carry out economic activities, and promote cultural assets (Carta di Siena, 2014). The issue of public participation is both a goal and a challenge highlighted by the European Landscape Convention and its implementation in practices bring up several critical points that need to be addressed (Jones \& Stenseke, 2011).

At European scale, networks have been founded for promoting cooperation among sectoral subjects aimed at implementing the Landscape Convention, such as the European network of universities (UNISCAPE), the European network of local and regional Authorities (RECEPENELC) and the European network of civil society organizations (CIVILSCAPE). Nevertheless, in a local perspective, the cooperation should be applied in a collaborative process among key local actors and researchers aimed at sharing local and expert knowledge, recognizing resources and values and planning actions for landscape management and sustainable development (Attardi et al., 2014; Clemente et al., 2015; Cerreta \& Daldanise, 2017). Therefore, the local community is fundamental to building consciousness of the place, to identifying and assessing its tangible and intangible resources (Dematteis \& Governa, 2005; Magnaghi, 2010a; Esposito De Vita et al., 2016), thus considering not only physical elements but also collective memories, meanings, and identities (Cerreta et al., 2014).

Local communities can be involved with interviews, questionnaires, personal stories, or participative mapping in order to turn shared values into a decision-making process and thus integrate local knowledge with the expertise of researchers (Antrop \& Van Eetvelde, 2017; Oppido et al., 2019). This place-based approach (Pugalis \& Bentley, 2014) is based on improvement of local partnerships, on the involvement and the empowerment of local community in decision processes for co-planning, co-designing and co-evaluating of the landscape. Besides, this approach is consistent with the National Strategy for Inner Areas in Italy, which is aimed at increasing development, competitiveness and attractiveness by using territorial capital and by strengthening territorial cohesion (Camagni et al., 2009; Atkinson, 
2013; Camagni \& Capello, 2013). Territorial capital is here understood as consisting of local resources of an area, thus including communities and local know-how.

For this purpose, the main challenge is the construction of a widespread collaborative arena among institutions, experts, stakeholders, local communities and key actors for sharing knowledge and responsibilities in order to contrast marginalization process, starting from local heritage and specifically, from multidimensional values recognized in the landscape (Innes \& Booher, 2002; Bailey, 2010; Bee \& Pachi, 2014; Horizon 2020 Expert Group on Cultural Heritage, 2015; Monno \& Khakee, 2016; Ferilli et al., 2016; Sager, 2016).

\section{Research design}

\subsection{The non-core area of Alta Irpinia: Issues and opportunities}

Authors have selected the Alta Irpinia non-core area and have focused on the AvellinoRocchetta Sant'Antonio historical railway and on initiatives around it. The main goal is to study the proactive role already played by local communities (Oppido et al., 2017), and also to set out the potentialities these communities could have in recognizing and promoting the non-core area landscape as driver for territorial regeneration. The case is characterized by:

- The excellence of the landscape distinguished by agricultural landscape, industrial landscape, protected natural landscape, and cultural and historical landscape;

- The historical railway linking Campania, Basilicata and Apulia regions;

- The length of this railroad (119 of $380 \mathrm{~km}$ of the unused railway in this region) and its engineering and architectural value;

- Civic activism initiatives against the closure of the railway;

- The introduction of the railway into formal protocols and regulations.

Additionally, Alta Irpinia has been selected as pilot area by the Italian Territorial Cohesion Agency among four non-core areas of Campania Region to test the Regional Strategy for Inner Areas (Agenzia per la Coesione Territoriale, 2016). This region of southern Italy, located between the Apennine Mountains and the Tyrrhenian Sea, is characterized by heterogeneous morphology, with relevant natural and cultural heritage, including UNESCO World Heritage Sites like Amalfi Coast, Naples historical centre, and Herculaneum and Pompeii archaeological sites. In this representative territory, Alta Irpinia is characterized by historical, cultural and natural resources, but not adequately appreciated. This area, bordering on other two non-core areas of Basilicata and Apulia regions, is part of the Avellino Province administratively divided in Alta Irpinia non-core area and Area Vasta (Figure 1). This latter is aimed at identifying common requirements for a homogeneous development of the 38 member municipalities (Furno, 2015; Internet 1). 


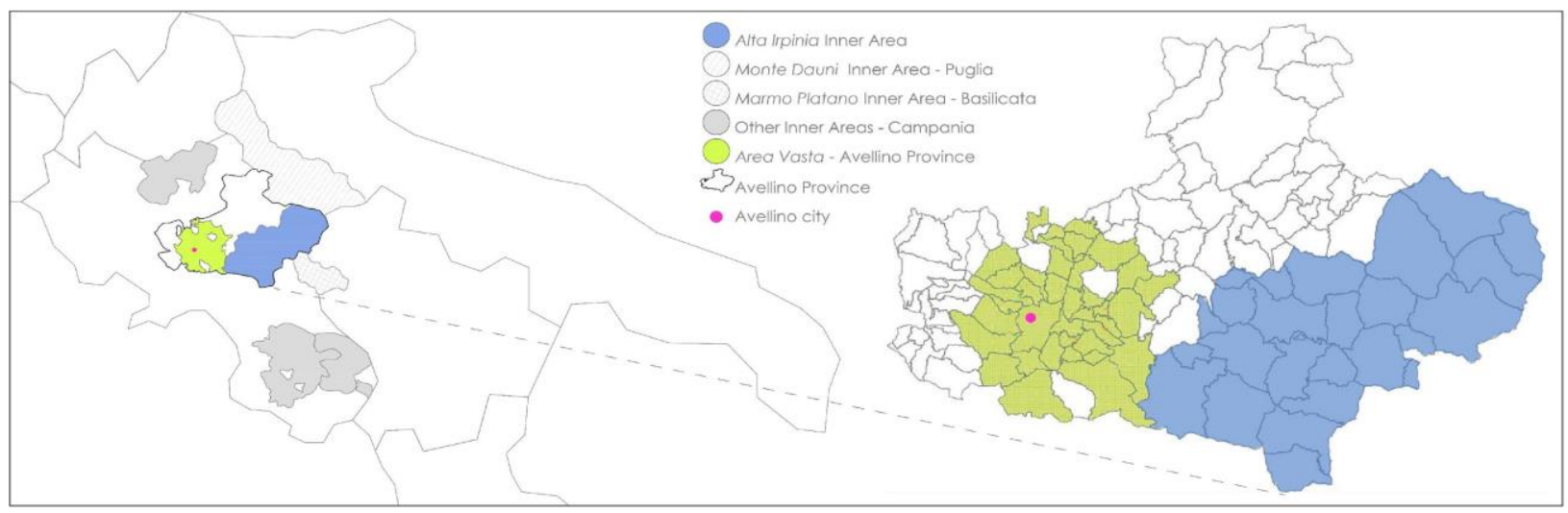

Figure 1: Territorial framework, Avellino Province and closest non-core areas (illustration: Serena Micheletti, source: Internet 1).

The main reason for strong criticisms of Alta Irpinia has been its fragmented and conflicting socio-political context due to the presence of 25 different municipalities that make disjointed decisions for local development. Conversely, the Regional planning identifies two homogeneous systems, one characterized by rural manufacturing sector (17 municipalities), and the other one by natural resources ( 8 municipalities).

In this wide territory of $1,118 \mathrm{~km}^{2}$ there are heterogeneous orographic configurations (mountains, valleys, caves, lakes, river-heads and rivers) that have determined different soil uses. These latter have generated several typologies of landscape such as agricultural landscape, including several Protected Designation of Origin products (wine, hazelnuts, chestnuts, olive oil, "Annurca" apple and wheat) (Internet 2), industrial landscape (wood, tanning, wind), protected natural landscape (sites of community importance, special protection areas, natural reserves and ecological networks and corridors), and cultural and historical landscape (Figure 2).

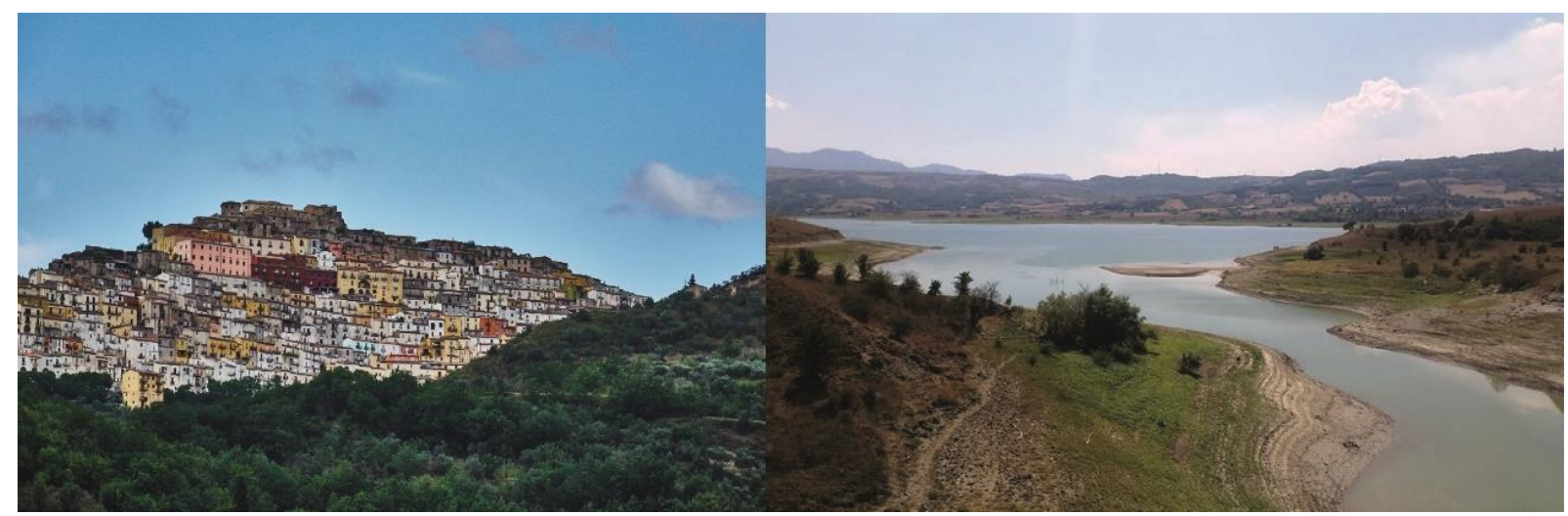

Figure 2: (a) Historical centre of Calitri (photo: Sabino Battista); (b) Conza Lake seen from the train (photo: Stefania Ragozino).

Despite the richness of this heritage, data show the on-going marginalization process of the area threatening the landscape heritage: from 2000 to 2011, the population decreased by $5.8 \%$, exceeding both the regional (1.4\%) and the national (2.3\%) average in non-core areas. In 2011, $23.7 \%$ of the population was over 65 years old, exceeding the regional and national average for non-core areas (Agenzia per la Coesione Territoriale, 2016; SNAI \& ISFORT, 2016). In 
addition, in the last years there was increased soil consumption (11\% of regional territory in 2016, exceeding the national rate of 7.6\%) (ISPRA, 2017; Internet 3).

\subsection{The Avellino-Rocchetta Sant'Antonio railway as strategic resource for Alta Irpinia}

Among the factors affecting the marginalization of Alta Irpinia non-core area, the ineffectiveness of the accessibility system is one of the main ones. Specifically, the inadequacy of road network and infrastructural system has been increasing in the last years. The situation was worsened by the suspension of the Avellino-Rocchetta Sant'Antonio railway in 2010. The role of this railway was double: not only it linked the city of Avellino with the non-core areas within the province, but it was also a strategical infrastructure that connected three neighbours regions - Campania, Basilicata and Apulia - from west to east of southern Italy.

The Avellino-Rocchetta Sant'Antonio railway was inaugurated in 1895 and it is $119 \mathrm{~km}$ long. Due to political and orographic reasons, it is characterized by an irregular track (Maggi, 2008; Pane, 2008); it is a non-electrified single-track network with two terminals, connected to the main hubs of urban poles, and 31 stations almost all replaced by prefabricated buildings after the 1980 earthquake (Internet 4). A complex engineering infrastructure was required to overcome both variable altitude - from 217 meters of the Rocchetta Sant'Antonio to 672 meters of Nusco - and to overpass the Sabato, Calore and Ofanto rivers, as highlighted in the Figure 3 (Società Italiana per le Strade Ferrate del Mediterraneo, 1898; Internet 5).

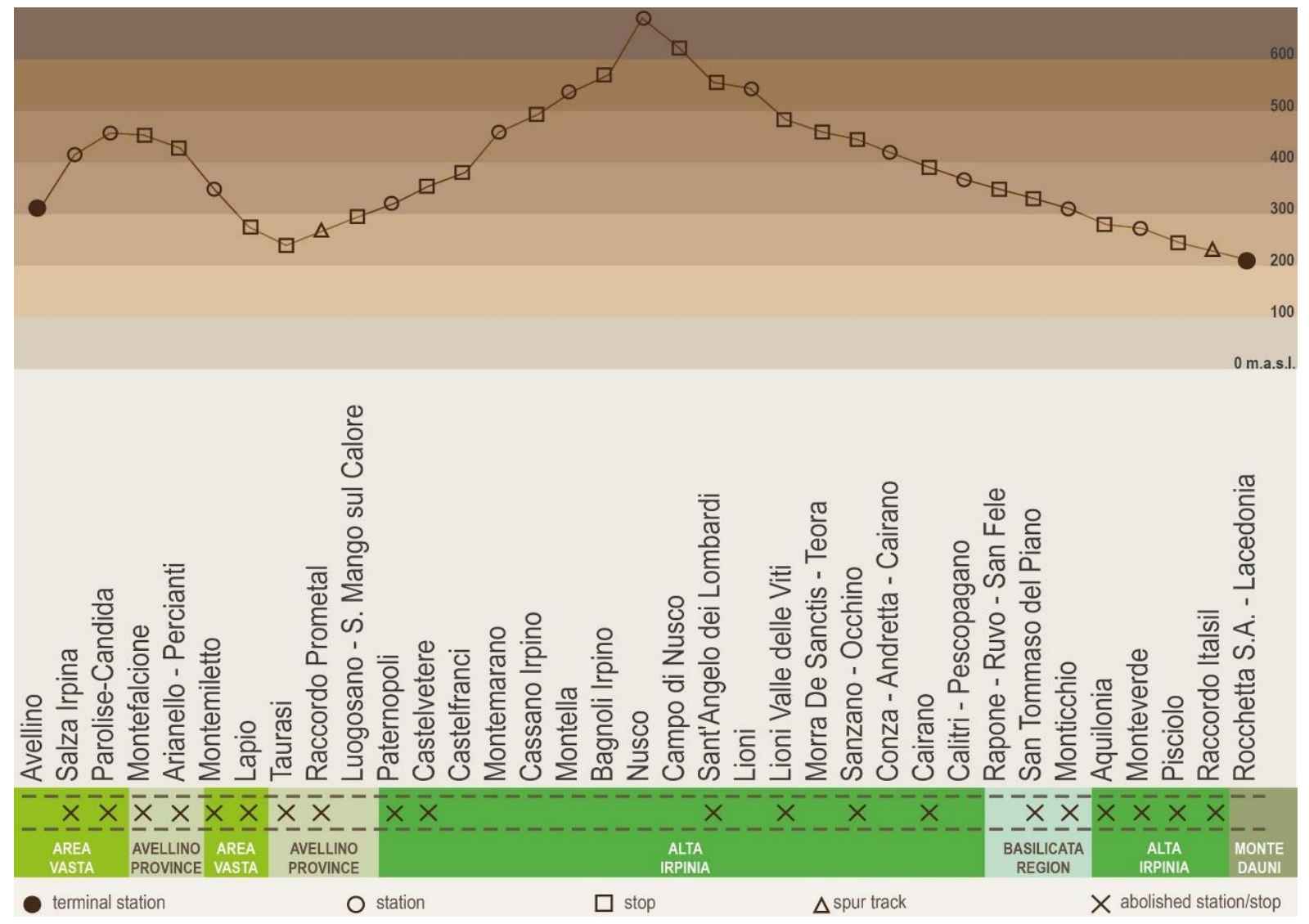

Figure 3: Stations and altitude (illustration: Serena Micheletti). 


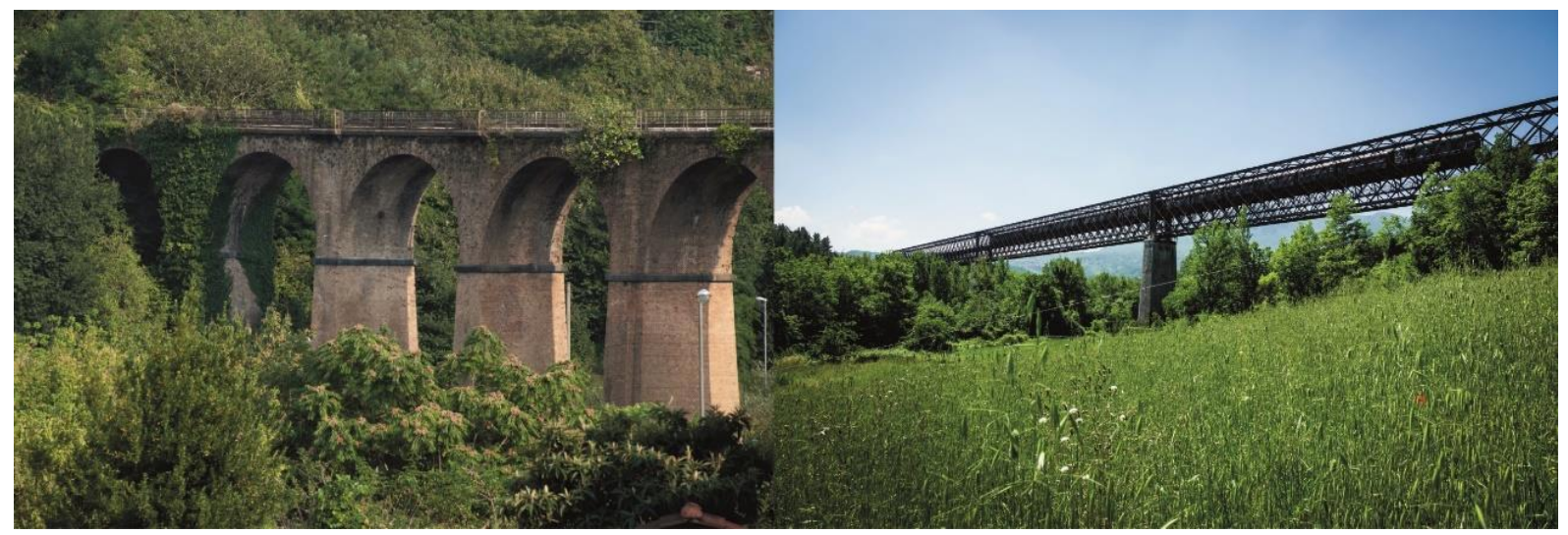

Figure 4: (a) Viaduct on the Sabato River (source: Internet 6); (b) Principe bridge (photo: Sabino Battista).

Among the other artworks belonging to industrial archaeology, 58 bridges and viaducts in steel or masonry are included in the infrastructure, such as the curvilinear viaduct on the Sabato River, with significant landscape value, and the Principe Bridge on the Calore River, renowned for its technological and dimensional features (Figure 4).

Since year 2000, the use of the railway declined, due to the considerable distance between stations and built-up areas, the low integration of railway system with mobility system, the incorrect planning of route schedules, the lengthy transit times for freight and passenger trains. Nevertheless, the local communities have protested against the definitive closure of the railway and have thus obtained its temporary suspension starting from 2010. Specifically, activists linked to the Avellino-Rocchetta Sant'Antonio railway became more consolidated during 2009, when the most active association, called In_Loco_Motivi, was founded by a group of small associations (Amici della Terra Irpina, Irpinia Turismo, RossoFisso, Irpinando), organizations, citizens and a labour union observatory. In order to keep a spotlight on this historic railway, they organized several activities (Internet 6). Among the discussed reuse options, they strongly opposed the possibility to turn it into a greenway (which would mean eliminating the railway) and preferred its tourism reuse. During 2009-2010, they organized several holiday packages to discover the territory and its resources through the historical railway. The initiative was named Irpinia Landscape Train (Ita. Treno Irpino del Paesaggio) and covered two Sunday train trips per month with excursions, lunch, cultural entertainment and guided tours. These trips attracted 2,051 visitors during 27 excursions (76 visitors per trip). Of these, three were organized for educational purposes (63 students per trip). The association rented an historical train, bought the tickets from the National Railway Agency (Ita. Ferrovie dello Stato Italiane), and designed a holiday package for visiting the landscape of Irpinia. Every visitor paid 15-35 Euros per package, including the trip in one or more of the 17 small villages crossed by the rail and some of more than 30 monuments of the area (In_Loco_Motivi archive). Due to the suspension of the railway line, the initiative was halted on December 13, 2010. In the last years, civic activism has preceded institutional actions: in fact, not until 2016 has this railway been included in formal protocols.

\subsection{Action Research: A collaborative method for marginalized contexts}

The challenging reuse of the Avellino-Rocchetta Sant'Antonio railway is an opportunity for the authors to reflect on the role of the community in regenerating publicness and cultural values of marginalized landscapes. They have selected this railway and the community around it in order to be part of the change by building new useful relationships through creating a stronger 
network for the locals to nourish social practices aimed at strengthening the sense of belonging and at sharing responsibilities for local development. Action Research (Bradbury-Huang, 2010; Reason \& Bradbury, 2001) is "a participatory, democratic process concerned with developing practical knowing in the pursuit of worthwhile human purposes, grounded in a participatory worldview which we believe is emerging at this historical moment. It seeks to bring together action and reflection, theory and practice, in participation with others, in the pursuit of practical solutions to issues of pressing concern to people, and more generally the flourishing of individual persons and their communities" (Reason \& Bradbury, 2001: 1). This method seeks to rearrange fragmented or conflicting perspectives (Kaneklin et al., 2010) and starts change from the bottom up by creating a reflecting and proactive community, which includes public and private stakeholders, associations, citizens, and researchers. The innovative element of the AR consists in the deliberate, mutual influence between research and action and context. The core of the practice could be summarized as trying to turn "a house into a home", whereby the conjunct work of local actors and researchers is brought forward within an organization or enterprise or, as in our case, within a consolidated group of people involved in a territorial issue (Kaneklin et al., 2010). Importantly, the AR is specifically used for working with marginalized communities living in unequal and vulnerable conditions. It has been argued that improving self-organization and collective learning is one of the best ways to obtain possible forms of emancipation, understood as ways to achieve social equity (Luhmann \& Febbrajo, 1990; Maturana \& Varela, 1991; Saija, 2017). Additionally, in contexts in which physical vulnerability, social marginalization and institutional gridlock challenge the quality and the sustainability of social relations, this method reinforces linkages and strategies through reciprocal collaboration between researchers and local actors.

In order to apply the method, literature and practice suggest three main phases of work: startup, continuation, and results. For this research, these established steps have been extended to include peculiarities of the reuse case of historic railway of Avellino-Rocchetta Sant'Antonio. The amended phases are: action research questions (1); inside out (2); arena (3); action (4); coevaluation (5). Each is characterized by different stages of work and tools (Figure 5):

- Action research questions: The first phase is devoted to the construction or consolidation of the research questions. AR allows both questions previously formulated by researchers to be shared with the community and questions to be formulated together with the community. In this phase, the researcher has the responsibility to identify the demands of the community or to recognize unexpressed desiderata. Possible tools include focus groups, interviews, questionnaires and participation in meetings through which latent or already recognized issues may be identified and defined.

- Inside out: During the second phase, issues that have been previously recognized are further specified through listening and interaction campaigns, during which researchers organize and/or participate in roundtables, focus groups and workshops with local actors and experts in order to discuss priorities, to overcome conflicts and to program the next steps. Researchers improve their knowledge of the territory through site visits promoted by the local associations. One of the tasks is to further stimulate the debate about the territorial values through sharing visual devices to illustrate the territory, highlight conflictual or positive dynamics and possible future scenarios. One of the selected tools is the community map.

- Arena: In this fundamental phase, general and specific objectives, including strategies, actions, and responsibilities are defined. Conflicts and overlapping interests usually emerge in this phase. The role of the researcher is to facilitate the communication and the interaction among the different actors. A permanent territorial laboratory is built, as a physical and symbolic place dedicated to the process of change. The goal of the laboratory is to create 
thematic working groups. Tools include roundtables, assemblies, focus groups, consultations, and simulations of scenarios.

- Action: Actors develop and promote strategies of change through thematic meetings, direct actions, and alternative initiatives of reuse of the territory. Community maps are the tool of choice for stimulating the community to express itself in a proactive way.

- Co-evaluation: in this phase, researchers and the community develop an assessment plan. It is structured in two stages: one of co-evaluation (Panaro, 2015) of the process and its results, and one of evaluation led by the researchers about validity of the research. The latter stage also seeks to identify takeaways for practice and research reports. At the same time, this reflection may also open up new questions for further research.

As highlighted in figure 5, this five-phase process is characterized by an iterative structure that provides continuous feedbacks from the field and coming back to previous phases of work in order to improve, enrich and frame them on the basis of the acquired information.

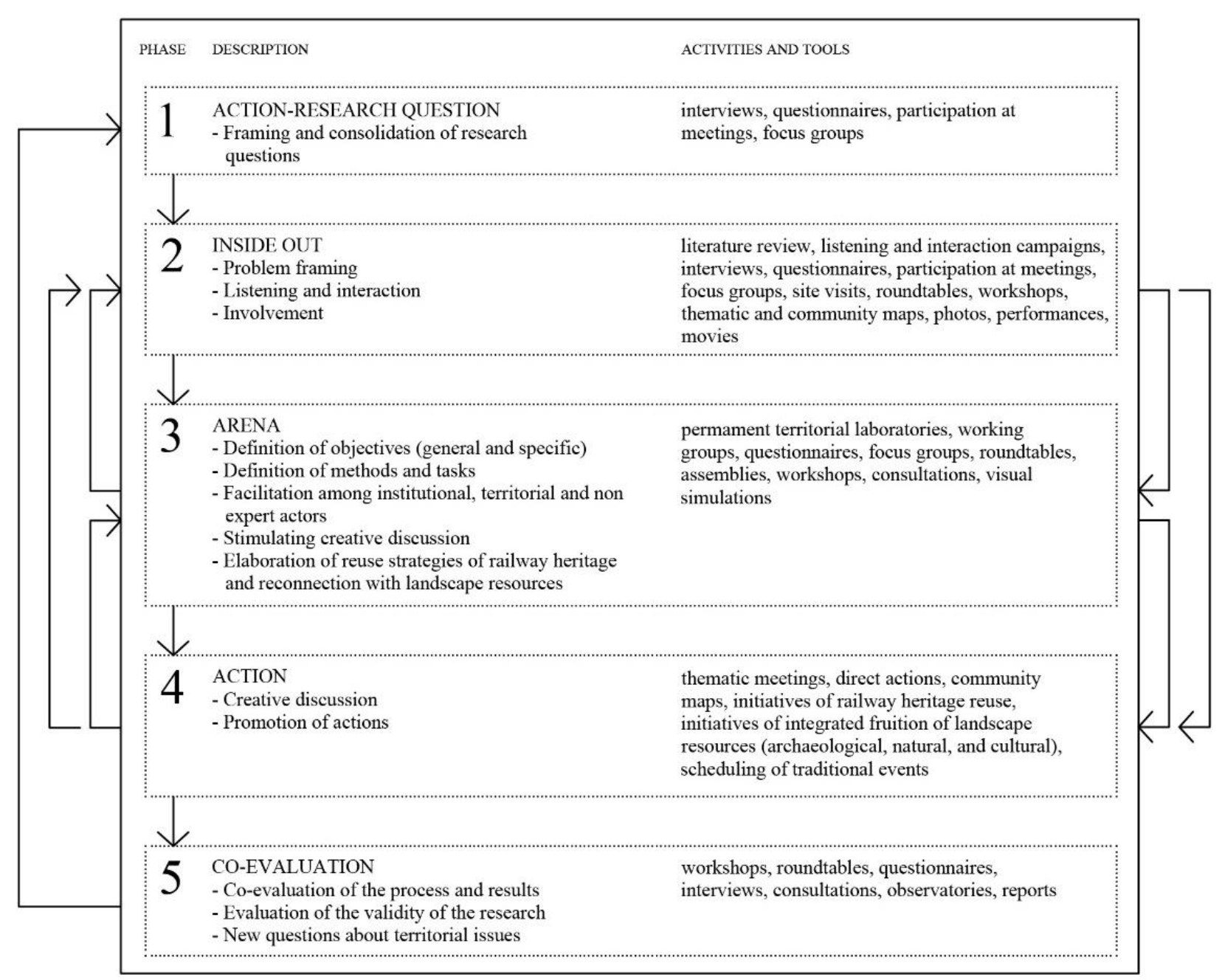

Figure 5: Methodology frame (illustration: Stefania Ragozino).

\section{Action research on the marginalization of Alta Irpinia}

This research started in January 2017. In May 2018 the authors implemented the first two phases and are now developing the third one. In the first phase, authors consolidated the pre- 
existing research questions and defined one question to be put to the community of Alta Irpinia. The first two are "What role can the local community play in sharing responsibility for reversing marginalization processes in non-core areas, starting from the reuse of the historical railway?" and "Can the landscape be the catalyst of social practices to activate new cultural, social, economic dynamics for a regeneration process of these areas?".

These two research questions are useful to analyse facts and perceptions, implement theory about community-based and bottom-up initiatives in reversing marginalization processes, and to identify the potential role of the landscape in social activation. The question addressed to the community of Alta Irpinia is: "How can we reuse the historical railway in order to enhance or reinforce its publicness and socio-cultural value for the whole territory of Alta Irpinia?" This bundle of questions has led different phases of AR.

Having understood the pivotal role of the In_Loco_Motivi association and its potential in organizing the reuse of the railway (Oppido et al., 2017), the authors first got in contact with the association. During the first meetings, the research group appreciated the heterogeneity of local representatives and the association's proactive role within the reuse process. Researchers were welcomed and included in organizational meetings (open to outsiders) in order to discuss the objectives of the AR. Together they examined the research questions, and they specifically focused on the publicness and socio-cultural value of the historical infrastructure and its potentials as a driver for local development. Local actors were interested in these contents and in finding new ways to bring launch the process. They also agreed on the proposed research questions and signalled the need to sustain their bottom-up initiatives. In order to do so, they introduced researchers to other important actors in the process: representatives of regional and local governments, scholars who had done previous research on the railway, professionals, school headmasters and local associations.

In the inside out phase, the authors deepened their analysis (Oppido et al., 2017) by conducting new site visits, consulting literature on the socio-economic history of the area, sociodemographic data and reports, planning documents, scientific dissertations, promotional brochures, official website, and reports of initiatives produced by institutional bodies and noninstitutional actors (Maggi, 2008; Pane, 2008; Gargiulo, 2009; Cerreta et al., 2012; SNAI \& ISFORT, 2016). They collected and systematized this material into technical and thematic maps supported by GIS, in order to analyse environmental, productive, cultural and socio-economic layers of the relevant territory and worked as a "neutral" starting point to open the debate and stimulate participants to draw their own maps. Community maps (Magnaghi, 2010b) were used to help participants represent their territory, landscapes, knowledge and traditions. Community maps can be arranged as tools to nourish a process of collective and personal self-representation to restore the sense of place by enabling the community to describe its territory as it perceives it. For these reasons, these maps contribute to guide researchers in the process of decoding of what is perceived as valuable. In this phase, researchers took part in local meetings and carried out interviews, selecting actors in order to cover the different categories and roles played by public and private stakeholders within initiatives concerning the railway. They contacted the national supervisor of the National Strategy for Inner Areas, executives of FS Foundation, Region of Campania, Superintendence of Avellino, Municipality of Avellino, Touring Club, Alliance for Slow Mobility (A.Mo.Do.), as well as local associations, headmasters, and professionals (architects, engineers, geologists, estimators). They informed the participants about the purposes of the research and sought to meet stakeholders, in order to identify roles and interests and to collect information about other actors involved in related initiatives. 
Since May 2017, researchers enlarged the actor network by including institutional subjects. The meeting held in Calitri was the first institutional event to which researchers were invited as experts. This was the first occasion to hear local politicians speak about the obstacles and projects for the development of the area. In July, the researchers were invited to participate in an expert task-force whose goal was to prepare a "Study Day" about the Avellino-Rocchetta Sant'Antonio Railway in November 2017. Researchers were also invited to collaborate in the design of the Masterplan for the sustainable local development in the area of the AvellinoRocchetta Sant'Antonio railway. Specifically, they were asked to give methodological support for the construction of the Masterplan. In August 2017 the research group took part both in the official opening and in the first trip on the historical train from Lioni to Rocchetta Sant'Antonio and back, held at the fifth edition of the "Sponz Fest". This festival is a rich, one-week programme of music, dancing and theatre events, performances, readings, meetings, movie and walking events, which in 2017 attracted 35,000 people. Through participation researchers were allowed to observe the tourism fluxes and the local civic engagement attracted by this event and to appreciate the potentialities of railway reuse in terms of cultural promotion of the Alta Irpinia, creation of new linkages between isolated villages, landscape and core-areas, and construction of a tourist destination, which can determine a new demand of accommodation services and facilities. Central and local governments and private bodies participated in the opening event, including representatives of Italian Parliament, FS Foundation, Campania Region and mayors of municipalities that use the railway. Researchers met the CEO and a member of the FS Foundation and initiated contact with this private body in order to frame the community-based reuse proposal within the FS Foundation strategy.

In the Arena phase the Municipality of Avellino invited the researchers to work as experts in several technical meetings with the Superintendence and In_Loco_Motivi members. The goal of these meetings was the definition of a draft Masterplan to be presented at the Study Day in November 2017. Anticipating new funds from the Campania Region and aiming at a collaborative planning, the Municipality of Avellino repeatedly met with mayors of municipalities crossed by the railway to collect proposals and desiderata about possible scheduling of cultural events and initiatives for recovery and reuse of local cultural heritage. Learning from several unsuccessful attempts at involving the local mayors, the Municipality of Avellino sought to lure them by leaving more room for their own ideas and projects for the reuse of the railway. In these contexts, researchers observed political and social dynamics among local actors, listened to different desiderata and proposals, and presented successful examples of already developed practices of railway reuse by focusing on applicable methods and tools, such as focus groups, territorial laboratories, cultural mapping and locative media. In this phase, during May 2018, the entire railway was renewed and launched with an official twoday trip in which the researchers participated and where they observed the local communities affection and the real potentialities of the whole infrastructural system enhancement. Conversely, researchers reported the lack of necessary services along the track in terms of hospitality and narration of the territory. On the other hand, only some subjects took the advantage of this event for spontaneous promotion of their local products. 


\section{Findings and discussion}

This section collects first findings related to the first three phases of the method presented previously. They mainly deal with obstacles and opportunities of physical context, and socioeconomic and political sphere.

First findings emerged during the observation of the Alta Irpinia territory - supported by the technical GIS mapping and implemented through interaction with local actors. They can be summarized in two points. The first one relates to the strength of the railway, which is barycentric with respect to the Alta Irpinia resources. In fact, the proposed buffer area includes archaeological, historical, cultural, environmental and productive sites that could be easily linked to the railway line (Figure 6). Conversely, the second point relates to weakness in terms of logistics, because the distance of the historical villages from the railway stations is problematic, especially in a view of the complex orography of Alta Irpinia. Many historical stations were demolished after a violent earthquake in 1980 and have been replaced with low quality prefabricated buildings. During the first site visits, researchers reported critical conditions of the railway stations and a real lack of an integrated system for the accessibility to the local resources, even if during the special events bus transfers had been provided. The low level of accessibility

has contributed to the marginalization process, although this same condition of segregation has protected the areas from negative aspects of the homologation processes that have affected the core areas.

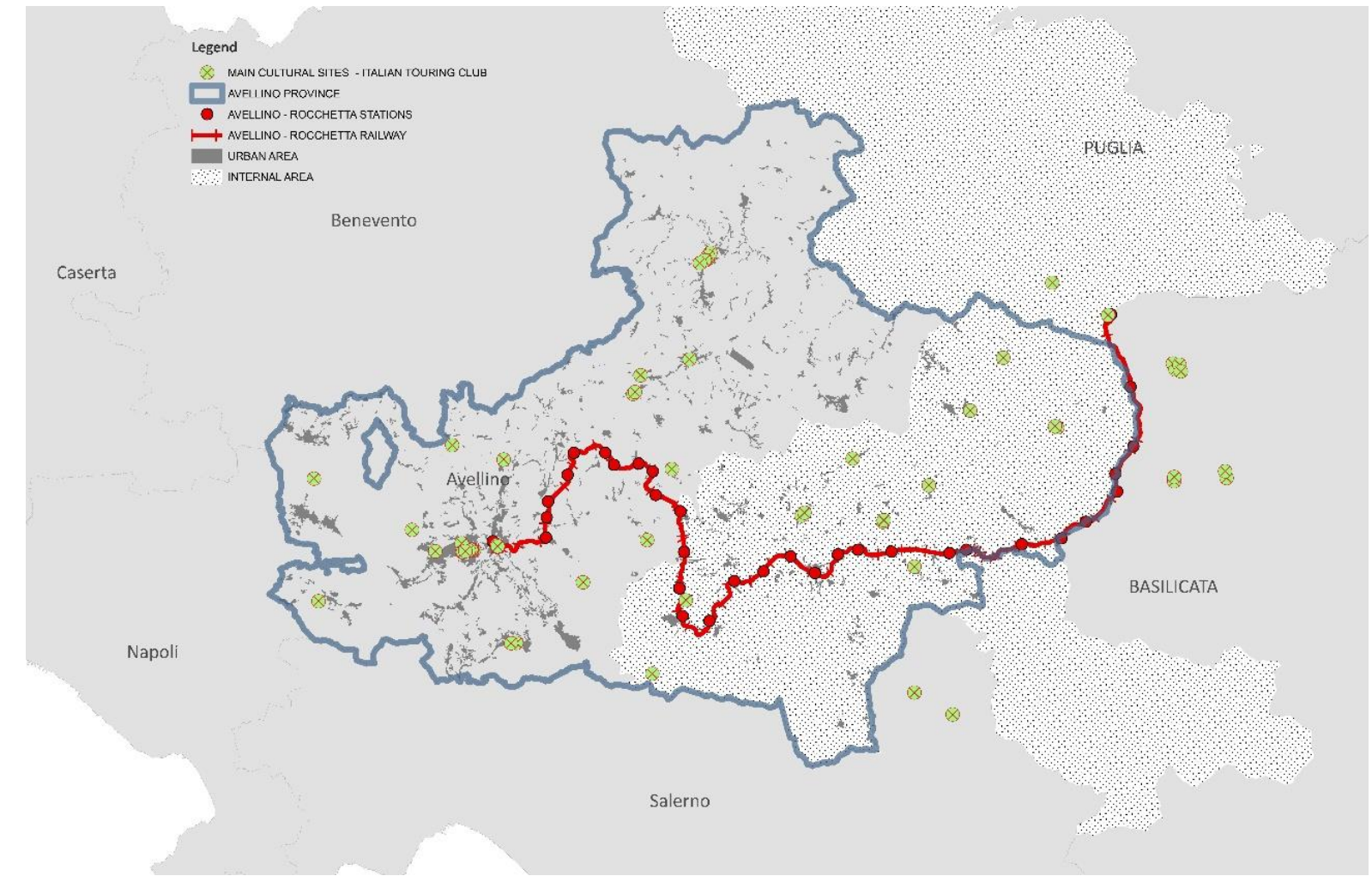

Figure 6: Barycentric position of the railway in the cultural resources system surveyed by the Italian Touring Club (illustration: Oppido et al., 2017; source: Internet 7).

From a socio-economic and political point of view, this phase has revealed the pivotal role that civic activism in general, and the In_Loco_Motivi association in particular, plays in creating 
local spontaneous arenas. This forerunning association has demonstrated in advance the potentialities of railway tourism, which are confirmed by the nation-wide increases of this sector in the last years: $45 \%$ in terms of visitors and $39 \%$ in terms of historical railway trips since 2015 (Internet 4).

In_Loco_Motivi has attracted local associations, citizens, school executives, experts and universities, and has motivated the sustained commitment of the FS Foundation. This network has allowed an effective engagement with the issue of railway reuse through a wider collaborative arena; in detail, the FS Foundation has progressively recovered the AvellinoRocchetta Sant'Antonio railway by including it in its national project for conservation and touristic reuse "Timeless Tracks" (Ita. Binari senza tempo; Internet 8).

The analysis of the social and political process and the visualization of the bottom-up and topdown actions have shown a near absence of the local governments and entrepreneurs until the summer of 2016. As shown in Figure 7, the interest and the engagement of local activists had already started in 1995. Institutional actions started only in 2016, when FS Foundation signed the Memorandum of Understanding for the opening of the track for touristic purposes. The only action carried out before this date was the Declaration of Cultural Interest of the historical railway: recognition of its engineering, historical and cultural value, which constitutes the starting point for the protection of this heritage. This public action has a nation-wide relevance as this was the first time that a Declaration of Cultural Interest targeted a whole system and not merely a single element

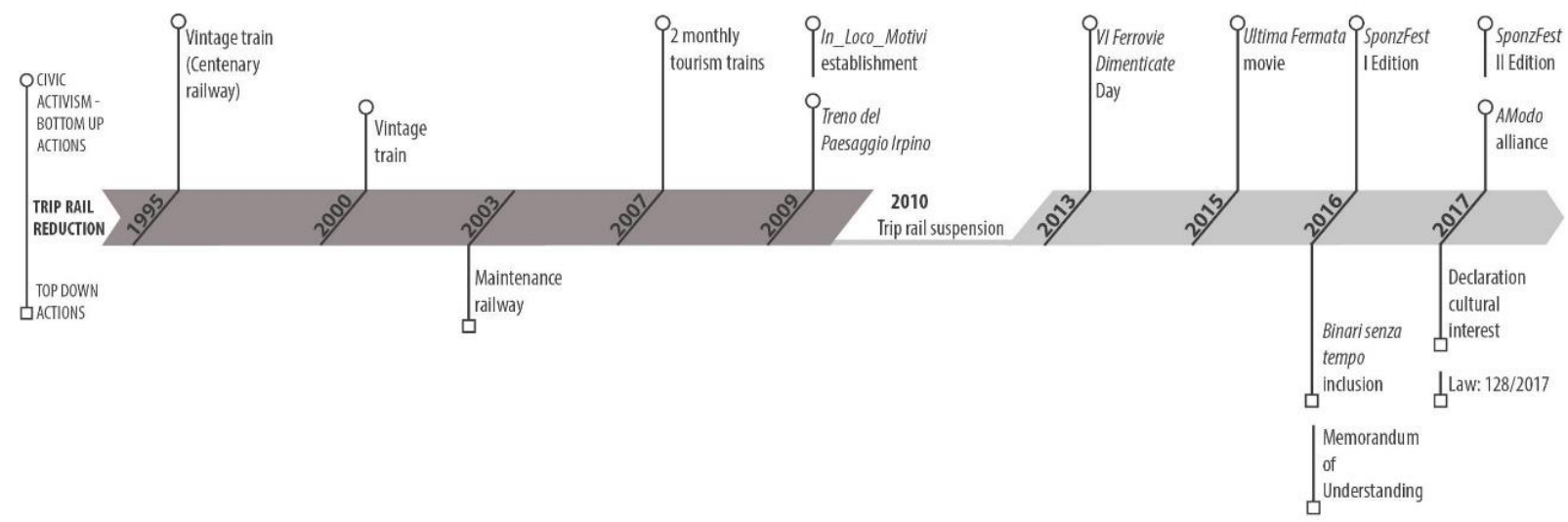

Figure 7: Civic activism and public action timeline (illustration: Serena Micheletti).

Importantly, the official opening of the first renewed part of the railway was the first tangible proof of cooperation between the FS Foundation and central and local governments. The train trips were included in the program of the Sponz Fest (Internet 8) and expressed the community's strong sense of belonging to the area. Local communities and visitors played an active role of cultural participation and animation by organizing a dense programme of activities on the train (performances, traditional music sessions and comedies) and in the stations during the train stops (traditional music sessions and welcome committees). The initiatives that were organized for the inauguration of the track showed the richness of the traditions of Alta Irpinia and the locals' affection for them (Figure 8). 


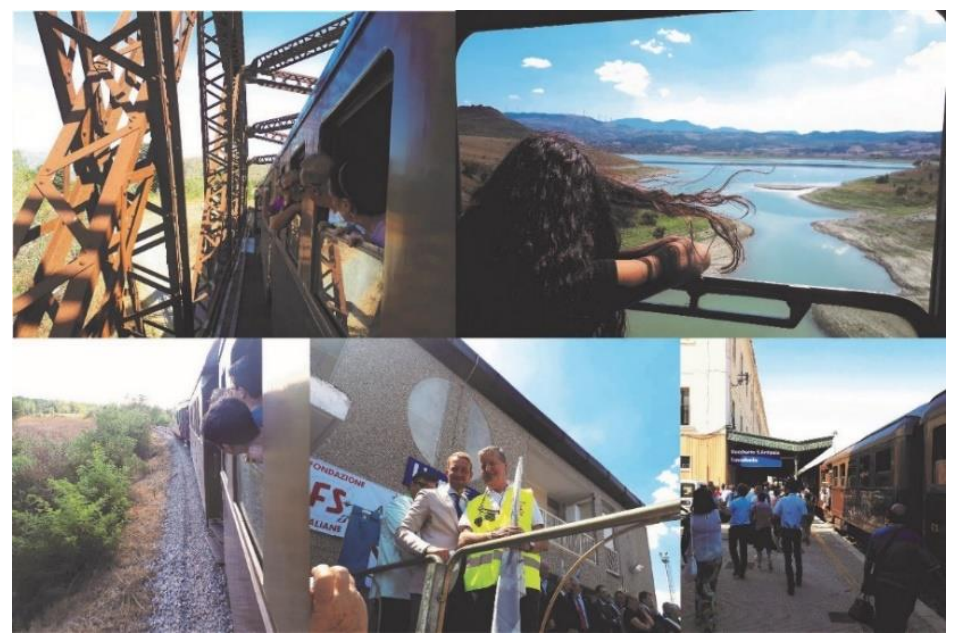

Figure 8: Photos from the reopening of the first part of the railway (photo: Stefania Ragozino).

During the active observation sessions, researchers intercepted relevant subjects to introduce to the arena for a collaborative process. They could be divided into four main categories, related to civic activism, public action, private initiative and research activity (Figure 9).

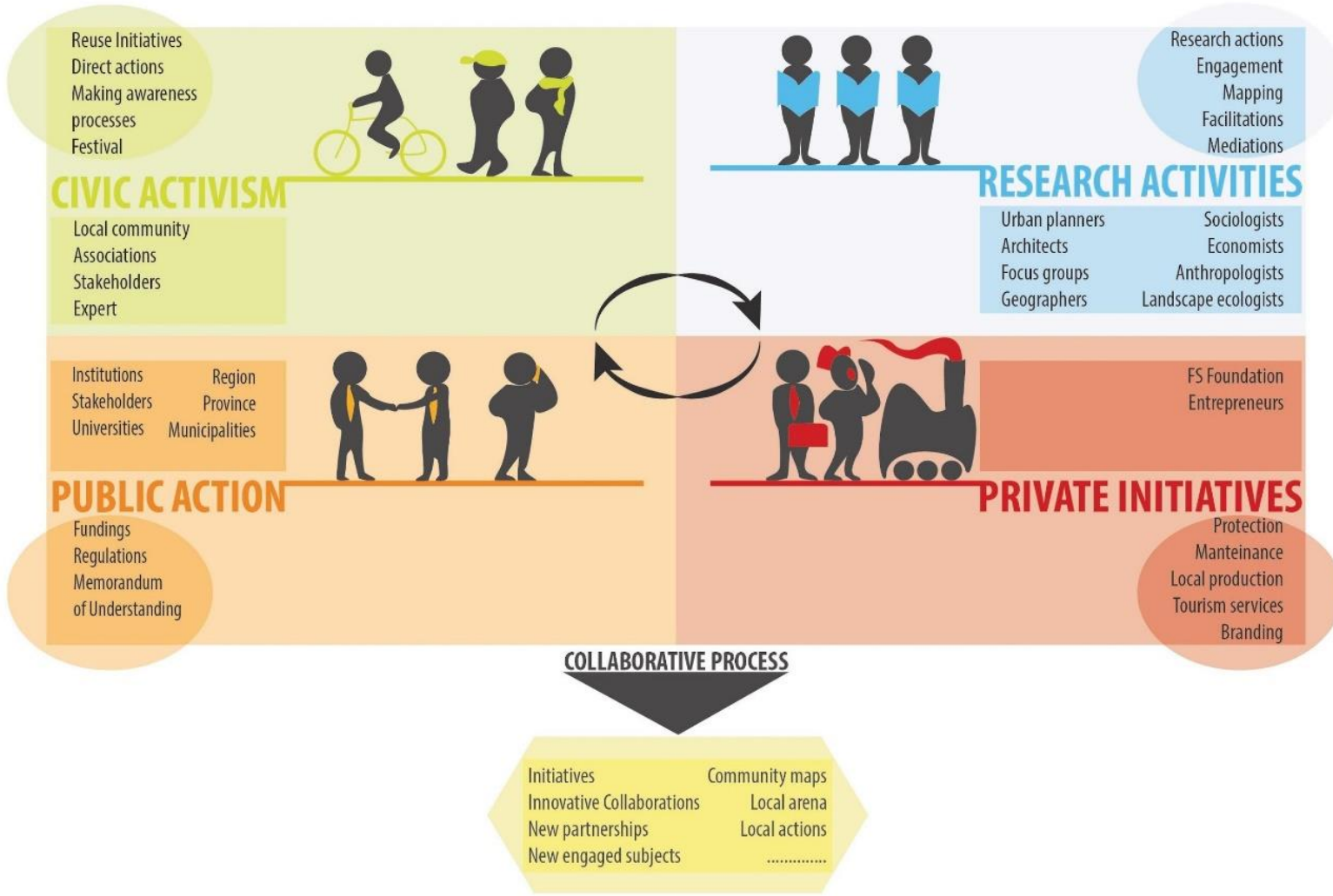

Figure 9: Actors and actions of the collaborative process (illustration: Serena Micheletti).

Additionally, these first phases allow for a presentation of preliminary reflections about the publicness and socio-cultural values of landscape. On one hand, the scientific debate highlights these values among those recognized in the landscape by current multidisciplinary approaches (Stephenson, 2008; Makhzoumi et al., 2011; Settis, 2013; Antrop \& Van Eetvelde, 2017). On the other hand, these values have been catalysts for activism initiatives inspired by the richness of the Irpinia landscape to enhance its role as common ground for redeeming marginalized 
areas. The initiative "Irpinia Landscape Train" is aimed at telling, sharing and improving collectively the local identity, identified as driver for regeneration processes. A further step, already incorporated in the AR agenda, is to transfer this theme into institutional decisions, first of all the Masterplan for the sustainable local development in the area of the Avellino-Rocchetta Sant'Antonio railway as well as in the construction of a community destination.

As we are in the middle of the AR, we can conclude with a preliminary consideration about the awareness of the potentialities offered by landscape. Specifically in the case of Alta Irpinia, the landscape could be considered as a driver for local initiatives but also as a structural element through which to build a regeneration strategy for the territory. This reasoning has been validated by the mapping process that has highlighted the consistency and the quality of the landscape, as well as by the bottom-up and top-down initiatives that have confirmed the acknowledgment of the landscape as an element of local identity with a strong value of publicness. Additionally, the exchange of competencies and experiences, and the participation of researchers in local initiatives have contributed to new awareness of the concept of landscape. Specifically, researchers highlighted the potential role of the landscape not only as tourism asset but as driver to reverse the marginalization process in Alta Irpinia.

These first findings of the AR enable researchers to start a wider reflection on the publicness of the landscape in the non-core areas. The main challenge in these areas is the strengthening of the territorial cohesion (Barca, 2009), and the AR method allows for sharing of a knowledge system and decisions for local development, and thus of responsibilities for the future of the areas. This way of working is adequate to emphasize the publicness of landscape by activating an equal process of regeneration based on collective commitment to co-planning and co-design actions. The main goal is to rebuild ties between community and territory, and among different local actors, by activating self-recognition and self-organization of development processes (Oppido et al, 2019). The hardest challenge for these areas is related to the governance both in the phase of territorial resources interpretation and in the phase of planning. Indeed, we should strive for a method that would interpret the public value of the landscape and valorize it as community heritage for the social cohesion, instead of slipping into the heritage marketization drift.

Stefania Oppido, CNR-IRISS, Naples, Italy (s.oppido@iriss.cnr.it)

Stefania Ragozino, CNR-IRISS, Naples, Italy (s.ragozino@iriss.cnr.it)

Serena Micheletti,CNR-IRISS, Naples, Italy (s.micheletti@iriss.cnr.it)

Gabriella Esposito De Vita, CNR-IRISS, Naples, Italy (g.esposito@iriss.cnr.it)

\section{Acknowledgments}

This research is funded by the Italian Research Council (CNR) within the research project "Place-based Regeneration Strategies and Policies for Local Development", coordinated by Gabriella Esposito De Vita. This contribution is the result of the collaborative work of the four authors. Specifically, Stefania Oppido worked on $\S 1,2,4$ and 5, Stefania Ragozino on $\S 3.3,4$ and 5, Serena Micheletti on $\S 3.1$ and 3.2, and Gabriella Esposito De Vita on $\S 5$.

We are thankful to the association In_Loco_Motivi, and in particular to Pietro Mitrione, Valentina Corvigno and Luca Battista for the provided material, which was useful both for analysing the tangible and intangible heritage of the historical Avellino-Rocchetta Sant'Antonio railway and for redrawing the civic activism process of which they were and are protagonists. 


\section{References}

Agenzia per la Coesione Territoriale (2016) Preliminare di Strategia - Area Pilota Alta Irpinia.

Antrop, M. (2005) Why landscapes of the past are important for the future. Landscape and Urban Planning, 70(1), pp. 21-34. DOI: 10.1016/j.landurbplan.2003.10.002

Antrop, M. \& Van Eetvelde, V. (2017) Bringing it all together - Taking care of the landscape. In: Antrop, M. \& Van Eetvelde, V. (eds.) Landscape Perspectives, pp. 377-421. Berlin, Springer. DOI: 10.1007/978-94-0241183-6_12

Atkinson, R. (2013) Territorial capital, attractiveness and the place-based approach: The potential implications for territorial development. In: Pálné Kovács, I., Scott, J. \& Gál, Z. (eds.) Territorial cohesion in Europe Institute for Regional Studies, Centre for Economic and Regional Studies, pp. 297-308. Hungary, Hungarian Academy of Science.

Attardi, R., Cerreta, M., Franciosa, A. \& Gravagnuolo, A. (2014) Valuing cultural landscape services: a multidimensional and multi-group SDSS for scenario simulations. In: Murgante, B., Misra, S., Rocha, A.M.A.C., Torre, C.M., Rocha, J.G., Falcão, M.I., et al. (eds.) Computational Science and Its Applications ICCSA 2014. Lecture Notes in Computer Science, 8581. Cham, Springer.

Bailey, N. (2010) Understanding community empowerment in urban regeneration and planning in England: Putting policy and practice in context. Planning Practice and Research, 25(3), pp. 317-332. DOI: $10.1080 / 02697459.2010 .503425$

Barca, F. (2016) Diseguaglianze territoriali e bisogno sociale - La sfida delle "Aree Interne", Testo della Lezione per la decima Lettura annuale Ermanno Gorrieri. Modena, Fondazione Ermanno Gorrieri per gli studi sociali.

Barca, F. (2009) An agenda for a reformed cohesion policy. A place-based approach to meeting European Union challenges and expectations. Independent Report for the Regional Policy Commission.

Becattini, G. (2015) La coscienza dei luoghi. Il territorio come soggetto corale. Roma, Donzelli Editore.

Bee, C. \& Pachi, D. (2014) Active citizenship in the UK: Assessing institutional political strategies and mechanisms of civic engagement. Journal of Civil Society, 10(1), pp. 100-117. DOI: $10.1080 / 17448689.2014 .895604$

Bonesio, L. (2007) Paesaggio, identità e comunità tra locale e globale. Reggio Emilia, Diabasis.

Bradbury-Huang, H. (2010) What is good action research? Why the resurgent interest? Action Research, 8(1), pp. 93-109. DOI: 10.1177/1476750310362435

Camagni, R., Borri, D. \& Ferlaino, F. (2009) Per un concetto di capitale territoriale. In: Borri, D., \& Ferlaino, F. (eds.) Crescita e sviluppo regionale: strumenti, sistemi, azioni pp. 66-90 Milano, FrancoAngeli.

Camagni, R. \& Capello, R. (2013) Regional competitiveness and territorial capital: A conceptual approach and empirical evidence from the European Union. Regional Studies, 47(9), pp. 1383-1402. DOI: $10.1080 / 00343404.2012 .681640$

Cerreta, M. \& Daldanise, G. (2017) Community branding (Co-Bra): A collaborative decision making process for urban regeneration. In: Gervasi, O., Murgante, B., Misra, S., Borruso, G., Torre, C.M., Rocha, A.M.A.C., et al. (eds.) Computational Science and Its Applications - ICCSA 2017, 10406. pp. 730-746. Cham, Springer. DOI: 10.1007/978-3-319-62398-6_52

Cerreta, M., Inglese, P., Malangone, V. \& Panaro, S. (2014) Complex values-based approach for multidimensional evaluation of landscape. In: Murgante, B., Misra, S., Rocha, A.M.A.C., Torre, C.M., Rocha, J.G., Falcão, M.I., et al. (eds.) Computational Science and Its Applications - ICCSA 2014. Lecture Notes in Computer Science, 8581. Cham, Springer.

Cerreta, M., Panaro, S. \& Cannatella, D. (2012) Multidimensional spatial decision-making process: Local shared values in action. Computational Science and Its Applications-ICCSA 2012, pp. 54-70. DOI: 10.1007/978-3642-31075-1_5

Clemente, M., Arcidiacono, C., Giovene di Girasole, E. \& Procentese, F. (2015) Trans-disciplinary approach to maritime-urban regeneration in the case study "Friends of Molo San Vincenzo", port of Naples, Italy. In: Santoz Cruz s., Brandao Alves, F., Pinho, P. (eds) Citta 8th Annual Conference on Planning Research Aesop tg/Public Spaces \& Urban Cultures Meeting Generative Places, Smart Approaches, Happy People, pp. 701718. Porto, AESOP.

Council of Europe (2005) Framework convention on the value of cultural heritage for society. Faro.

Dematteis, G. \& Governa, F. (eds.) (2005) Territorialità, sviluppo locale, sostenibilità: il modello SLoT. Milano, FrancoAngeli.

Esposito De Vita, G., Trillo, C. \& Martinez-Perez, A. (2016) Community planning and urban design in contested places. Some insights from Belfast. Journal of Urban Design, 21(3), pp. 320-334. DOI: 10.1080/13574809.2016.1167586 
Ferilli, G., Sacco, P. L., Tavano Blessi, G. \& Forbici, S. (2016) Power to the people: when culture works as a social catalyst in urban regeneration processes (and when it does not). European Planning Studies, 24(11), pp. 1-18.

Furno, E. (2015) Il nuovo governo dell'area vasta: Province e Città metropolitane alla luce della cosiddetta legge Delrio nelle more della riforma costituzionale degli enti locali. Federalismi. It - Osservatorio Città Metropolitane.

Gargiulo, C. (2009) Reti di città, mobilità e ambiente: il Preliminare di PTCP di Avellino. Tema; Journal of Land Use, Mobility and Environment, 2(4), pp. 41-50.

Horizon 2020 Expert Group on Cultural Heritage (2015) Getting cultural heritage to work for Europe. Brussels, European Commission.

Innes, J., \& Booher, D. (2002) Network power in collaborative planning. Journal of planning education and research, 21(3), pp. 221.236.

Internet 1: https://www.cialpcaprigliairpina.wordpress.com (accessed July 2017).

Internet 2: http://www.siat.provincia.avellino.it (accessed May 2017).

Internet 3: https://www.legambiente.it (accessed May 2017).

Internet 4: http://www.ferroviedimenticate.it (accessed 11 Sept. 2017).

Internet 5: http://www.lestradeferrate.it (accessed July 2017).

Internet 6: http://www.avellinorocchetta.wordpress.com (accessed 12 Sept.2017).

Internet 7: https://www.touringclub.it/ (accessed 23 Mar. 2017).

Internet 8: https://www.fondazionefs.it (accessed 14 June 2017).

Internet 9: https://rm.coe.int/16800cce47 (accessed 10 July 2017).

ISPRA (2017) Consumo di suolo, dinamiche territoriali e servizi ecosistemici. Available on: http://www.isprambiente.gov.it/it/pubblicazioni/statistiche-download (accessed 17 Sept. 2018)

Jones, M. \& Stenseke, M. (2011) The European landscape convention: Challenges of participation, 13. Berlin, Springer Science \& Business Media.

Kaneklin, C., Galuppo, L. \& De Carlo, A. (2010) Dalla costruzione della committenza allo sviluppo dei committenti: l'avvio di una ricerca-azione. In: Kaneklin, C., Piccardo, C. \& Scaratti, G. (eds.) La ricercaazione. Cambiare per conoscere nei contesti organizzativi. Milano, Cortina.

Luhmann, N. \& Febbrajo, A. (1990) Sistemi sociali: fondamenti di una teoria generale. Bologna, Il mulino.

Maggi, S. (2008) Le ferrovie. Bologna, Il Mulino.

Magnaghi, A. (2006) Dalla partecipazione all'autogoverno della comunità locale: verso il federalismo municipale solidale. Democrazia E Diritto, 3, pp. 134-151.

Magnaghi, A. (2010a) Il progetto locale. Verso la coscienza di luogo. Torino, Bollati Boringhieri.

Magnaghi, A. (2010b) Montespertoli. Le mappe di comunità per lo statuto del territorio. Firenze, Alinea Editrice.

Makhzoumi, J., Egoz, S. \& Pungetti, G. (2011) The right to landscape: Contesting landscape and human rights. Farnham UK, Ashgate Publishing Ltd.

Maturana, H. R. \& Varela, F. J. (1991) Autopoiesis and cognition: The realization of the living, 42. Berlin, Springer Science \& Business Media.

Monno, V. \& Khakee, A. (2016) Tokenism or political activism? Some reflections on participatory planning. International Planning Studies, 17(1), pp. 85-101. DOI: 10.1080/13563475.2011.638181

Németh, J. \& Schmidt, S. (2011) The privatization of public space: modelling and measuring publicness. Environment and Planning B: Planning and Design, 38(1), pp. 5-23. DOI: 10.1068/b36057

Oppido, S., Ragozino, S., Icolari, D. \& Micheletti, S. (2019) Landscape as driver to build regeneration strategies in inner areas. A critical literature review. In: Calabrò, F., Della Spina, L., Bevilacqua, C. (eds) New Metropolitan Perspectives. ISHT 2018. Smart Innovation, Systems and Technologies, 100, pp. 615-624. Cham, Springer

Oppido, S., Ragozino, S. \& Micheletti, S. (2017) Reusing heritage: activist planning for place-based regeneration processes. In José Antunes, F., Simões, J. M., Morgado, S., Marques da Costa, E., Cabral, J., Ramo, I. L., et al. (eds.), AESOP Annual Congress - Spaces of dialog for places of dignity: Fostering the European Dimension of Planning pp. 2236-224. Lisbon, Universidade de Lisboa.

Panaro, S. (2015) Landscape Co-Evaluation Approcci valutativi adattivi per la co-creatività territoriale e l'innovazione locale. Doctoral thesiss. Naples, Università Federico II di Napoli.

Pane, A. (2008) Alle origini dell'ingegneria ferroviaria in Campania: la costruzione della linea Avellino-Ponte S. Venere (1888-1895) e gli attuali problemi di conservazione. In: D’Agostino S. (ed.) Atti del $2^{\circ}$ Convegno Nazionale Storia dell'Ingegneria, pp. 1291-1300. Naples.

Poli, D. (2015) Il patrimonio territoriale fra capitale e risorsa nei processi di patrimonializzazione proattiva. In: Meloni B. (ed.) Aree interne e progetti d'area pp. 123-140. Torino, Rosenberg e Sellier.

Public Investment Evaluation Unit (UVAL) (2014). A Strategy for inner areas in Italy: definition, objectives, tools and governance. Materiali UVAL, (31). Available at: http://www.dps.gov.it/it/arint/index.html (Accessed 13 June 2017) 
Pugalis, L. \& Bentley, G. (2014) Place-based development strategies: Possibilities, dilemmas and ongoing debates. Local Economy, 29(4-5), pp. 561-572. DOI: 10.1177/0269094214541617

Reason, P. \& Bradbury, H. (2001) Handbook of action research: Participative inquiry and practice. London, Sage. Sager, T. (2016) Activist planning: a response to the woes of neo-liberalism? European Planning Studies, 4313, pp. 1-19. DOI: 10.1080/09654313.2016.1168784

Saija, L. (2017) La ricerca-azione in pianificazione territoriale e urbanistica. Milano, Franco Angeli.

Selman, P. (2006) Planning at the landscape scale. London, Routledge.

Settis, S. (2013) Il paesaggio come bene comune. Naples, La scuola di Pitagora.

SNAI \& ISFORT (2016) Alta Irpinia (Campania). Report d'Area. Valutazione ex-ante del Preliminare di Strategia relativa al settore trasporti. Rome.

Società Italiana per le Strade Ferrate del Mediterraneo (1898) Relazione sugli studi e lavori eseguiti dal 1885 al 1897, con un album di 71 tavole. Roma.

Stephenson, J. (2007) Many perceptions, one landscape. Landscape Review, 11(2), pp. 9-30.

Stephenson, J. (2008) The cultural values model: an integrated approach to values in landscapes. Landscape and Urban Planning, 84(2), pp. 127-139. DOI: 10.1016/j.landurbplan.2007.07.003 